\title{
Antibody frequency for Toxoplasma gondii and Neospora spp. in domiciliated and stray cats from Araguaína, Tocantins, Eastern Amazonia
}

\section{Frequência de anticorpos para Toxoplasma gondii e Neospora spp. em gatos domiciliados e errantes de Araguaína, Tocantins, Amazônia Oriental}

\author{
Taiã Mairon Peixoto Ribeiro ${ }^{1 *}$; Thássia Silva Reis²; Sebastiana Adriana Pereira \\ Sousa3; Lucas Marlon Freiria4; Fábio Alves Gomes5; Giane Regina Paludo1; \\ Kledir Anderson Hofstaetter Spohr6; Marcos Rogério André7; \\ Helcileia Dias Santos²; Valéria De Sá Jayme ${ }^{8}$
}

\section{Highlights}

First report of antibodies against T. gondii and Neospora spp. in cats from Araguaína. There was no difference in the risk of infection between domiciliated and stray cats. Cats with defined breed have more risk to Neospora spp. infection.

\begin{abstract}
Toxoplasma gondii and Neospora spp. are protozoa that have a significant impact on animal health due to the diseases they cause in domestic and wild animals. The aim of the present study was to investigate the presence of antibodies against T. gondii and Neospora spp. in cats from northern Brazil. Serum samples were collected from 180 cats in the municipality of Araguaína, Tocantins and used to evaluate the presence

1 Drs. Researchers, Faculty of Agronomy and Veterinary Medicine, Universidade de Brasília, UnB, Brasília, DF, Brazil. E-mail: taia.ribeiro@unb.br; giane@unb.br

2 Profs. Drs., School of Veterinary Medicine, Universidade Federal do Tocantins, UFT, Araguaína, TO, Brazil. E-mail: thassiareis@uft.edu.br; hdsantos@uft.edu.br

${ }^{3}$ Prof $^{a} \mathrm{Dr}^{\mathrm{a}}$, Institute of studies of the humid tropic, Universidade Federal do Sul e Sudeste do Pará, UNIFESSPA, Xinguara, PA, Brazil. E-mail: adriana.sousa@unifesspa.edu.br

${ }^{4}$ Student of the Stricto Sensu Graduate Program at the Master's level in Health and Sustainable Animal Production in the Western Amazon, Universidade Federal do Acre, UFAC, Rio Branco, AC, Brazil. E-mail: lucas.m.freiria@gmail.com

5 Prof. Dr., Instituto Federal de Educação, Ciência e Tecnologia de Roraima, IFRR, Caracaraí, RR, Brazil. E-mail: fabio. gomes@ifrr.edu.br

${ }^{6}$ Prof. Dr., Faculty of Veterinary Medicine, Universidade Federal de Mato Grosso, UFMT, Cuiabá, MT, Brazil. E-mail: kledirspohr@gmail.com

7 Prof. Dr., School of Agricultural and Veterinary Studies, Universidade Estadual Paulista "Júlio de Mesquita Filho", UNESP/FCAV, Jaboticabal, SP, Brazil. E-mail: marcosandre.fcav@gmail.com

8 Profa $^{\mathrm{Dr}}{ }^{\mathrm{a}}$, School of Veterinary, Universidade Federal de Goiás, UFG, Goiânia, GO, Brazil. E-mail: sa.jayme@ufg.br

* Author for correspondence
\end{abstract}

Received: June 12, 2021 - Approved: Nov. 29, 2021 
of anti-T. gondii and anti-Neospora spp. antibodies using the indirect fluorescent antibody test, with a cutoff of 1:64 and 1:25, respectively. The association between infection and individual animal characteristics (age, sex, origin, breed, and clinical signs) was tested using univariate analysis, followed by multivariate logistic regression. We found that $48.3 \%$ (87/180) of the animals had anti-T. gondii (95\% Cl: $40.8 \%-55.90 \%)$ and $3.9 \%$ (7/180) had anti-Neospora spp. (95\% Cl: 1.6\%-7.8\%) antibodies. There was no association between age, sex, breed origin, clinical signs, and seropositivity for T. gondii. Cats of defined breeds were more likely to be infected by Neospora spp. (OR = 10.7). Therefore, we found a high rate of seropositivity for $T$. gondii and a high rate of occurrence of Neospora infections in cats from the Araguaína region. The exposure of the feline population to the studied coccidia indicates the need to monitor the feline population for these infections and underscores the importance of effective sanitary measures against such pathogens.

Key words: Felines. Neosporosis. Public Health. Toxoplasmosis.

\section{Resumo}

Toxoplasma gondii e Neospora spp. são protozoários com impacto relevante na saúde animal devido às doenças que causam em animais domésticos e silvestres. $O$ objetivo do presente estudo foi investigar a presença de anticorpos contra T. gondii e Neospora spp. em gatos do norte do Brasil. Amostras de soro foram coletadas de 180 gatos no município de Araguaína, Tocantinse utilizadas para avaliar a presença de anticorpos anti-T. gondii e anti-Neospora spp. pela reação de imunofluorescência indireta, utilizando um ponto de corte de 1:64 e 1:25, respectivamente. Associação da infecção com as caracteristicas individuais dos animais (idade, sexo, origem, raça e sinais clínicos) foram testadas por meio de análise univariada, seguida de análise multivariada por regressão logistica. Como resultado, 48,3\% (87/180) dos animais apresentaram anticorpos anti-T. gondii (IC 95\%: 40,8\% -55,90\%) e 3,9\% (7/180) anti-Neospora spp. (IC 95\%: 1,6\% -7,8\%). Não foi encontrada associação entre idade, sexo, raça, origem e presença de sinais clínicos e a soropositividade para $T$. gondii. Gatos com raça definida apresentaram maior chance de infecção por Neospora spp. $(\mathrm{OR}=10,7)$. Portanto, registra-se elevada soropositividade de gatos para $T$. gondii e a ocorrência de infecção por Neospora em gatos da região de Araguaína, Tocantins. A exposição da população felina aos coccídios estudados indica a necessidade de monitoramento da população de felinos quanto a estas infecções e aplicação de medidas sanitárias eficazes contra tais patógenos.

Palavras-chave: Felinos. Neosporose. Saúde pública. Toxoplasmose.

\section{Introduction}

Currently, the population of cats in Brazilian households is estimated to be 22.1 million 9Instituto Brasileiro de Geografia e Estatística [IBGE], 2015). The domestic cat has retained its predation instinct even though domestication occurred more than 10,000 years ago. However, this instinct is associated with the transmission of diseases of clinical relevance in feline medicine, such as toxoplasmosis (Karakavuk et al., 2018).

Toxoplasma gondii is a cosmopolitan protozoan with an impact on public health, and its definitive hosts are several species of felids. In addition to water intake and ingestion of uncooked meat, these mammals become infected through the predation of rodents and birds (Aguirre et al., 2019). Clinical signs of feline toxoplasmosis include 
muscle hyperesthesia, pneumonia, hepatitis, dyspnea, tachypnea, jaundice, diarrhea, fever, and seizures (Hartmann et al., 2013).

Infection of cats with Neospora caninum and Neospora hughesi has also been demonstrated experimentally (CerqueiraCézar, Calero-Bernal, Dubey, \& Gennari, 2017). These infections result in musculoskeletal necrosis, necrotizing hepatitis, pneumonia, tubular renal necrosis, and transplacental transmission of $N$. caninum (Dubey \& Lindsay, 1989; Dubey, Lindsay, \& Lipscomb, 1990).

There have been few investigations on the circulation of T. gondii and Neospora spp. in cats in the northern region of Brazil. This area covers the Amazon ecosystem, where cats are present in $22.7 \%$ of households (IBGE, 2015; Calero-Bernal \& Gennari, 2019). It is noteworthy that these animals can become a source of environmental dissemination and infection in humans because of the fecal elimination of $T$. gondii oocysts in felines (Teixeira et al., 2019).

Because of the relevance of these protozoa in veterinary medicine and the diseases that they cause in felines, this study aimed to investigate the presence of antibodies against T. gondii and Neospora spp. in cats in the municipality of Araguaína (Tocantins) and to verify their association with epidemiological variables.

\section{Materials and Methods}

\section{Study area}

The municipality of Araguaína $\left(7^{\circ} 11^{\prime} 28^{\prime \prime} S\right.$ and $\left.48^{\circ} 12^{\prime} 26^{\prime \prime} \mathrm{W}\right)$ is located in the northern region of Tocantins in the Brazilian
Eastern Amazon Region. The Aw (hot and humid with a winter dry season) type climate predominates, with an average annual temperature of $26^{\circ} \mathrm{C}$ and average rainfall of $1,869 \mathrm{~mm}$ per year, and a rainy period from October to April (Penereiro, Martins, \& Beretta, 2016).

\section{Sample and data collection}

The convenience sampling method was used in this study. The study sample consisted of 180 blood samples collected from domestic cats from veterinary care facilities and cats caught by the Araguaína Zoonoses Control Center from 2015 to 2018.

After the study was explained to them, the owners authorized the collection of biological samples from the animals on their property by signing an informed consent form. At the time of blood collection, the animals were physically restrained and underwent a clinical examination (including medical history, measurement of temperature and capillary filling time, and abdominal palpation), and data of the individual characteristics were collected.

After the initial examination, approximately 1-4 $\mathrm{mL}$ of blood from the cephalic or jugular vein was collected using a vacuum suction system in tubes with tripotassium ethylenediaminetetraacetic acid (K3 EDTA) and tubes with a coagulation activator. The serum samples obtained after centrifugation were stored at $-20^{\circ} \mathrm{C}$ in sterile polystyrene microtubes.

The individual epidemiological characteristics evaluated were age $(\geq 6$ months or $<6$ months), sex (male or female), 
clinical signs (presence or absence of any signs of a clinical abnormality after complete medical history was obtained and physical examination performed), breed (defined breed or no defined breed), and origin (stray or domiciliated).

Detection of anti-T. gondii and anti-Neospora spp. IgG antibodies

IgG antibodies against $T$. gondii and Neospora spp. were detected using the indirect fluorescent antibody test (IFAT), based on tachyzoite antigens from the $T$. gondii RH strain and tachyzoite antigens from N. caninum isolate $\mathrm{NC}-1$.

The serum was diluted with $1 x$ phosphate-buffered saline, and 1:64 and 1:25 dilutions were used as cutoffs for positivity for T. gondii and Neospora spp., respectively (Camargo, 1964; Braga et al., 2012). The samples considered positive ( $\geq 1: 64$ for $T$. gondii and 11:25 for Neospora spp.) were titrated in dilutions with a base dilution factor of 2 until fluorescence occurred. Goat anticat IgG conjugate labeled with fluorescein isothiocyanate (F4262; Sigma-Aldrich, St. Louis, MO, USA) was diluted to 1:64 to perform the test.

The reading was performed in a dark room with a microscope equipped for fluorescence (Model Eclipse E200; Nikon, Tokyo, Japan) at 40x magnification. Samples that showed complete fluorescence of the tachyzoite surface used as antigens were considered positive.

\section{Statistical analysis}

The analysis of the association between the presence or absence of anti- $T$. gondii and anti-Neospora spp. antibodies in the feline population and epidemiological variables (age, sex, clinical signs, and origin) were performed using univariate analysis, followed by unconditional logistic regression using Epilnfo 7.2. ${ }^{\circledR}$ Variables with a P-value $<0.25$ were included in the logistic regression model.

A two-tailed chi-square $\left(\chi^{2}\right)$ statistical method with Yates correction and Fisher's exact test was used. The threshold for statistical significance was set at $P \leq 0.05$.

The study was approved by the Animal Use Ethics Committee of the Federal University of Tocantins (protocol No. 23101.000.988/2018-10).

\section{Results and Discussion}

The frequency of antibodies against T. gondii was $48.3 \%$ (87/180; $95 \% \mathrm{Cl}: 40.8 \%-$ $55.9 \%)$, and the titers were $1: 64(n=53), 1: 128$ ( $n=20), 1: 256(n=11), 1: 2048(n=2)$, and $1: 4096(n=1)$.

The frequency of antibodies against $T$. gondii found in the present study was lower than that found in the studies conducted by Magalhães et al. (2017) on the island of Fernando de Noronha-PE (71.26\%; 248/348), which can be attributed to the fact that these researchers used a lower cutoff for IFAT (IFAT cut-off value of $\geq 1: 16$ ) than in the present study. 
Environmental and cultural differences may also have influenced the frequency of T. gondii infection. No restriction of movement, predation of birds and rodents, and consumption of uncooked meat products by stray and domestic cats, may increase the frequency of $T$. gondii infection.

The frequency of antibodies against $T$. gondii was similar to that reported by Braga et al. (2012) in São Luís-MA (50.5\%; 101/200) and Feitosa et al. (2014) in Patos-PA (43.8\%; $88 / 201)$. Such results may be attributed to the environmental similarities between Araguaína and São Luís. Both localities are in the Amazon Biome, where sporulation of oocysts is favored due to the large area of preserved forests close to the urban area and the hot and humid climate. The results found in Patos, in the state of Paraíba, can be attributed to the lowest established cutoff (1:16), which favors greater sensitivity of the technique. However, such samples were obtained from regions with unfavorable environmental conditions (semi-arid) (Feitosa et al., 2014).

Lower T. gondii frequency values than those in the present study have been reported by other authors in Brazil using IFAT with different cut-offs: for instance, Sousa et al. (2014) in Campo Grande-MS (32.5\%; 49/151; 1:40), Souza et al. (2015) in Rio Branco-AC (24.7\%; 22/89; 1:64), Caldart et al. (2015) in Londrina-PR (20.9\%; 87/415; 1:16) and Koch et al. (2019) in Curitiba-PR (21\%; 21/100; 1:50).
The difference in frequency reported in these previous studies may be related to the fact that cats in the countryside and peripheral regions are widely used to control rodent and synanthropic bird populations, have free outdoor access, and are frequently fed uncooked meat. In addition, these cats are not often seen by veterinarians, thus increasing the risk of exposure to T. gondii (Mendes-de-Almeida et al., 2007).

The frequency of seropositivity suggests that there is exposure to T. gondii in the feline population in the municipality. Furthermore, some animals could have an active infection, at least those with titers above 1:1024 (Bresciani et al., 2007). The three animals that had the highest titers (1:4096 and 1:2048) were less than 6 months old and showed clinical signs such as ataxia of the pelvic limbs, splenomegaly, and uveitis. Despite being non-specific, these clinical signs are compatible with cases of feline toxoplasmosis (Calero-Bernal \& Gennari, 2019). Although morbidity rates are low for felines, the high frequency of $T$. gondii infection in the municipality may indicate that detectable titers in sick animals are possible.

No significant association was found between age, sex, breed, presence of any clinical alteration. or animal origin, and seropositivity for T. gondii (Table 1). 


\section{Table 1}

Results of univariate and multivariate analysis for individual characteristics and infection for Toxoplasma gondii in cats from the municipality of Araguaína, Tocantins, Brazil

\begin{tabular}{|c|c|c|c|c|c|c|c|}
\hline \multirow[b]{2}{*}{ Variable } & \multirow[b]{2}{*}{$\begin{array}{l}\text { Total } \\
(180)\end{array}$} & \multirow[b]{2}{*}{$\begin{array}{c}\text { Positives } \\
\mathrm{N}(\%)\end{array}$} & \multicolumn{3}{|c|}{ Univariate } & \multicolumn{2}{|c|}{ Multivariate } \\
\hline & & & $\begin{array}{c}\text { Crude } \\
\text { odds ratio }\end{array}$ & Cl 95\% & P-value & $\begin{array}{l}\text { Adjusted odds } \\
\text { ratio (IC 95\%) }\end{array}$ & P-value \\
\hline \multicolumn{8}{|l|}{ Age } \\
\hline Young & 30 & 16 (53.3) & 1.27 & $0.58-2.79$ & 0.69 & - & - \\
\hline Adult & 150 & $71(47.3)$ & & & & & \\
\hline \multicolumn{8}{|l|}{ Sex } \\
\hline Male & 81 & $33(40.7)$ & 1.74 & $0.94-3.17$ & 0.09 & $0.55(0.30-1.01)$ & 0.054 \\
\hline Female & 99 & 54 (54.5) & & & & & \\
\hline \multicolumn{8}{|l|}{ Clinical signs } \\
\hline Present & 51 & $31(60.8)$ & 2.02 & $1.04-3.91$ & 0.05 & $1.77(0.83-3.76)$ & 0.139 \\
\hline Absent & 129 & $56(43.4)$ & & & & & \\
\hline \multicolumn{8}{|l|}{ Origin } \\
\hline Stray & 73 & $40(54.8)$ & 1.55 & $0.85-2.83$ & 0.20 & $0.80(0.41-1.59)$ & 0.525 \\
\hline Domiciled & 107 & 47 (43.9) & & & & & \\
\hline \multicolumn{8}{|l|}{ Breed } \\
\hline Defined breed & 8 & 07 (87.5) & 7.98 & $1.198-184.6$ & $0.02^{*}$ & $6.91(0.80-60.02)$ & 0.080 \\
\hline No defined breed & 172 & $80(46.5)$ & & & & & \\
\hline
\end{tabular}

*Fisher exact test.

In previous studies, a relationship with older age was found because older animals have been exposed to parasites for longer than younger animals have and can re-eliminate oocysts when infected with heterologous strains (Bresciani et al., 2007; Cardia, Camossi, Silveira, Langoni, \& Bresciani, 2013; Feitosa et al., 2014; Zulpo et al., 2018); however, the results of our study indicate that young and adult animals are exposed to a similar risk of infection.

The lack of association observed for the sex variable corroborates the findings of Bresciani et al. (2007) and Cruz et al. (2011), although there is an indication that females may be more resistant to parasitic infections than males because of a more effective immune response (Morales-Montor et al., 2004). Although in the univariate analysis, the breed was associated with seropositivity for T. gondii (OR $=7.98)$, this was not seen in the logistic regression analysis $(P=0.08)$. A similar result was reported by Souza et al. (2015).

Although domiciliated cats were expected to have a lower risk of infection because they had more preventive care, this was not observed. Environmental or social characteristics, such as cats having unrestrictedaccess to outdoorareasand being fed uncooked food (meat products and byproducts), lead to a different epidemiological scenario, and such characteristics are more 
relevant than the origin of the animal (Feitosa et al., 2014).

Regarding Neospora spp., the frequency of antibodies was verified in 3.9\% (95\% Cl: $1.6 \%-7.8 \%)$ of the sampled animals, and titers were 1:25 $(n=5), 1: 50(n=1)$, and $1: 100(n=1)$.

By assessing the frequency of antibodies against Neospora spp. (3.9\%), it can be inferred that there is a low rate of infection by the pathogen in the feline population. Only two animals had titers above the 1:25 cutoff, demonstrating, in addition to the small number of infected animals, a low rate of seroconversion, corroborating the results of another study (Sedlák, Bartova, \& Machacova, 2014). According to Meneses et al. (2014) and Feitosa et al. (2014), natural infections in cats by Neospora spp. have never been reported, which could suggest low seroconversion or resistance to the pathogen, despite reports of experimental infection in immunosuppressed animals.

The frequency of antibodies against Neospora spp. found in felines from Araguaína was lower than that reported by Bresciani et al. (2007) in São Paulo (24.5\%; 100/400; 1:16), Braga et al. (2012) in Maranhão (27\%; 54/200: 1:25), and Koch et al. (2019) in Paraná (42\%; 42/100; 1:50). However, the frequency of antibodies against Neospora spp. was similar to that reported by Sousa et al. (2014) in Mato Grosso do Sul (6.6\%; 10/151), by Lima et al. (2018) on the Island of Fernando de Noronha (3.11\%; 8/257), and by Meneses et al. (2014) in Bahia (2.9\%; 8/272). Therefore, the percentage of frequency of Neospora spp. observed nationally were lower than those observed for T. gondii. However, such an occurrence is expected, as Neospora spp. appear to be less widespread than T. gondii. With the exception of Lima et al. (2018), who used the agglutination technique and a 1:20 cutoff, the other authors mentioned above used IFAT with a 1:50 cutoff.

Except for breed, no other epidemiological variables evaluated were associated with seroreactivity to Neospora spp. (Table 2). Bresciani et al. (2007) also observed a higher frequency of seropositivity for Neospora in animals of a defined breed. However, they found no statistically significant differences between the two groups. The breed was identified as an associated factor because a higher frequency was found in animals of a defined breed $(P<0.05)$, which may suggest a greater exposure of these animals to sources of infection. However, it is worth noting that the confidence interval was quite large due to the small number of animals of a defined breed, which could have influenced the results. 


\section{Table 2}

Results of univariate and multivariate analysis for individual characteristics and infection for Neospora spp. in cats from the municipality of Araguaína, Tocantins, Brazil

\begin{tabular}{|c|c|c|c|c|c|c|c|}
\hline \multirow[b]{2}{*}{ Variable } & \multirow[b]{2}{*}{$\begin{array}{l}\text { Total } \\
(180)\end{array}$} & \multirow[b]{2}{*}{$\begin{array}{c}\text { Positives } \\
\text { N(\%) }\end{array}$} & \multicolumn{3}{|c|}{ Univariate } & \multicolumn{2}{|c|}{ Multivariate } \\
\hline & & & $\begin{array}{l}\text { Crude } \\
\text { odds ratio }\end{array}$ & Cl 95\% & P-value & $\begin{array}{l}\text { Adjusted odds } \\
\text { ratio (IC 95\%) }\end{array}$ & P-value \\
\hline \multicolumn{8}{|l|}{ Age } \\
\hline Young & 30 & 1 (3.3) & 0.82 & $0.09-7.14$ & 0.73 & - & - \\
\hline Adult & 150 & $6(4.0)$ & & & & & \\
\hline \multicolumn{8}{|l|}{ Sex } \\
\hline Male & 81 & $4(4.9)$ & 1.66 & $0.36-7.65$ & 0.79 & - & - \\
\hline Female & 99 & $3(3.0)$ & & & & & \\
\hline \multicolumn{8}{|l|}{ Clinical signs } \\
\hline Present & 51 & $3(5.9)$ & 1.95 & $0.42-9.05$ & 0.66 & - & - \\
\hline Absent & 129 & $4(3.1)$ & & & & & \\
\hline \multicolumn{8}{|l|}{ Origin } \\
\hline Stray & 73 & $5(6.8)$ & 3.86 & $0.73-20.46$ & 0.19 & $0.27(0.05-1.47)$ & 0.130 \\
\hline Domiciled & 107 & $2(1.9)$ & & & & & \\
\hline \multicolumn{8}{|l|}{ Breed } \\
\hline Defined breed & 8 & $2(25)$ & 10.75 & $1.23-68.31$ & $0.03^{*}$ & $10.70(1.62-70.6)$ & 0.014 \\
\hline No defined breed & 172 & $5(2.9)$ & & & & & \\
\hline
\end{tabular}

*Fisher exact test.

There was no significant difference in sex, corroborating the findings of Bresciani et al. (2007). In the present study, age was not associated with seroreactivity to Neospora spp., which differs from the findings of Bresciani et al. (2007).

It is important to highlight that frequency studies are fundamental as they act as a direct indicator of the degree of spread of infectious and parasitic agents and are the basis for preventive measures for sanitary control in animals; consequently, they directly reflect on human health when dealing with zoonoses (Calero-Bernal \& Gennari, 2019).

\section{Conclusions}

This study reported the presence of antibodies against T. gondii and Neospora spp. in cats of Araguaína, highlighting the high proportion of cats that are seropositive for T. gondii. Cats of defined breeds were more likely to be infected by Neospora spp. Further studies are needed to assess other epidemiological variables that allow for a better understanding of the epidemiological scenario for the two coccidians in the feline population in the region. 


\section{References}

Aguirre, A. A., Longcore, T., Barbieri, M., Dabritz, H., Hill, D., Klein, P. N.,... Sizemore, G. C. (2019). The one health approach to toxoplasmosis: epidemiology, control, and prevention strategies. Ecohealth, 16(2), 378-390. doi: 10.1007/s10393019-01405-7

Braga, M. S. C. O., André, M. R., Jusi, M. M. G., Freschi, C. R., Teixeira, M. C. A., \& Machado, R. Z. (2012). Occurrence of antiToxoplasma gondii and anti-Neospora caninum antibodies in cats with outdoor access in São Luís, Maranhão, Brazil. Revista Brasileira de Parasitologia Veterinária, 21(2), 107-111. doi: 10. 1590/ S1984-29612012000200007

Bresciani, K. D. S., Gennari, S. M., Serrano, A. C. M., Rodrigues, A. A. R., Ueno, T., Franco, L. G.,... Amarante, A. F. T. (2007). Antibodies to Neospora caninum and Toxoplasma gondii in domestic cats from Brazil. Parasitology Research, 100(2), 281-285. doi: 10.1007/s00436-006-0262-4

Caldart, E. T., Constantino, C., Pasquali, A. K. S., Benitez, A. N., Hamada, F. N., Dias, R. C. F.,... Freire, R. L. (2015). Zoonosis in dogs and cats attended by the birth control project: Toxoplasma gondii, Leishmania spp. and Leptospira spp., serodiagnosis and epidemiology. Semina: Ciências Agrárias, 36(1), 253-266. doi: 10.5433/1679-0359.2015v36n1p253

Calero-Bernal, R., \& Gennari, S. M. (2019). Clinical toxoplasmosis in dogs and cats: an update. Frontiers in Veterinary Science, 6(1), 54. doi: 10.3389/fvets.2019.00054

Camargo, M. E. (1964). Improved technique of indirect immunofluorescence for serological diagnosis of toxoplasmosis. Revista do Instituto de Medicina Tropical de São Paulo, 6(1), 117-118. Retrieved from https://www.imt.usp.br/wp-content/ uploads/revista/vol06/117-118.pdf

Cardia, D. F. F., Camossi, L. G., Silveira, L., Neto, Langoni, H., \& Bresciani, K. D. S. (2013). Prevalence of Toxoplasma gondii and Leishmania spp. infection in cats from Brazil. Veterinary Parasitology, 197(3-4), 634-637. doi: 10.1016/j.vetpar. 2013.07.017

Cerqueira-Cézar, C. K., Calero-Bernal, R., Dubey, J. P., \& Gennari, S. M. (2017). All about neosporosis in Brazil. Revista Brasileira de Parasitologia Veterinária, 26(3), 253-279. doi: 10.1590/S1984-29 612017045

Cruz, M. A., Ullmann, L. S., Montaño, P. Y., Hoffmann, J. L., Langoni, H., \& Biondo, A. W. (2011). Seroprevalence of Toxoplasma gondii infection in cats from Curitiba, Paraná, Brazil. Revista Brasileira de Parasitologia Veterinária, 20(3), 256258. doi: 10.1590/S1984-29612011000 300016

Dubey, J. P., \& Lindsay, D. S. (1989). Transplacental Neospora caninum infection in cats. Journal of Parasitology, 75(5), 765-771. doi: 10.2307/3283062

Dubey, J. P., Lindsay, D. S., \& Lipscomb, T. P. (1990). Neosporosis in cats. Veterinary Pathology, 27(5), 335-339. doi: 10.1177/ 030098589002700505

Feitosa, T. F., Vilela, V. L. R., Dantas, E. S., Souto, D. V. O., Pena, H. F. J., Athayde, A. C. R., \& Azevedo, S. S. (2014). Toxoplasma gondii and Neospora caninum in domestic cats from the Brazilian semi- 
arid: seroprevalence and risk factors. Arquivo Brasileiro de Medcina Veterinária e Zootecnia, 66(4), 1060-1066. doi: 10.1590/1678-6696

Hartmann, K., Addie, D., Belák, S., BoucrautBaralon, C., Egberink, H., Frymus, T.,... Horzinek, M. C. (2013). Toxoplasma gondii infection in cats: $A B C D$ guidelines on prevention and management. Journal of Feline Medicine and Surgery, 15(7), 631637. doi: 10.1177/1098612X13489228

Instituto Brasileiro de Geografia e Estatística (2015). Pesquisa Nacional de saúde: acesso e utilização dos serviços de saúde, acidentes e violências: Brasil, grandes regiões e unidades da federação. Rio de Janeiro, RJ: Instituto Brasileiro de Geografia e Estatística.

Karakavuk, M., Aldemir, D., Mercier, A., Atalay Şahar, E., Can, H., Murat, J. B.,... Döşkaya, M. (2018). Prevalence of toxoplasmosis and genetic characterization of Toxoplasma gondii strains isolated in wild birds of prey and their relation with previously isolated strains from Turkey. PLoS One, 13(4), e0196159. doi: 10.1371/ journal.pone.0196159

Koch, M. O., Laskoski, L. M., Aguiar, D. M., Silva, B. R., Régio, R. R., Ishikura, J. I.,... LocatelliDittrich, R. (2019). Detection of antibodies against Sarcocystis neurona, Neospora caninum and Toxoplasma gondii in horses, dogs and cat. Brazilian Journal of Veterinary Research and Animal Science, 56(2), 1-8. doi: 10.11606/issn.1678-4456. bjvras.2019.152918

Lima, D. C. V., Magalhães, F. J. R., Andrade, M. R., Silva, J. G., Morais, E. G. F., Lima, C. D. F., Fo.,... Mota, R. A. (2018). Anti-Neospora caninum antibodies in feral cats on the
Island of Fernando de Noronha, Brazil. Acta Parasitologica, 63(3), 645-646. doi: 10.1515/ap-2018-0074

Magalhães, F. J. R., Ribeiro-Andrade, M., Souza, F. M., Lima, C. D. F., Fo., Biondo, A. W., Vidotto, O.,... Mota, R. A. (2017). Seroprevalence and spatial distribution of Toxoplasma gondii infection in cats, dogs, pigs and equines of the Fernando de Noronha Island, Brazil. Parasitology Internacional, 66(2), 43-46. doi: 10.1016/j. parint.2016.11.014

Mendes-de-Almeida, F., Labarthe, N., Guerrero, J., Faria, M. C., Branco, A. S., Pereira, C. D.,... Pereira, M. J. S. (2007). Follow-up of the health conditions of an urban colony of free-roaming cats (Felis catus Linnaeus, $1758)$ in the city of Rio de Janeiro, Brazil. Veterinary Parasitology, 147(1-2), 9-15. doi: 10.10 16/j.vetpar.2007.03.035

Meneses, I. D., Andrade, M. R., Uzêda, R. S., Bittencourt, M. V., Lindsay, D. S., \& Gondim, L. F. P. (2014). Frequency of antibodies against Sarcocystis neurona and Neospora caninum in domestic cats in the state of Bahia, Brazil. Revista Brasileira de Parasitologia Veterinária, 23(4), 526529. doi: 10.1590/S1984-29612014080

Morales-Montor, J., Chavarria, A., De León, M. A., Del Castillo, L. I., Escobedo, E. G., Sánchez, E. N.,... Larralde, C. (2004). Host gender in parasitic infections of mammals: an evaluation of the female host supremacy paradigm. Journal of Parasitology, 90(3), 531-546. doi: 10.1645/ GE-113R3

Penereiro, J. C., Martins, L. S., \& Beretta, V. Z. (2016). Identificação de variabilidade e tendências interanuais em medidas hidro-climáticas na região hidrográfica 
do Tocantins-Araguaia, Brasil. Revista Brasileira de Climatologia, 18(1), 219-241. doi: 10.5380/abclima.v18i0.38840

Sedlák, K., Bartova, E., \& Machacova, T. (2014). Seroprevalence of Neospora caninum in cats from the Czech Republic. Acta Parasitologica, 59(2), 359-361. doi: 10.24 78/s11686-014-0246-y

Sousa, K. C. M., Herrera, H. M., Domingos, I. H., Campos, J. B. V., Santos, I. M. C., \& Neves, H. H. (2014). Serological detection of Toxoplasma gondii, Leishmania infantum and Neospora caninum in cats from an area endemic for leishmaniasis in Brazil. Revista Brasileira de Parasitologia Veterinária, 23(4), 449-455. doi: 10.1590/ S1984-29612014078

Souza, S. F., Medeiros, L. S., Belfort, A. S., Cordeiro, A. L. L., Federle, M., Souza, A.
P., \& Moura, A. B. (2015). Toxoplasma gondii antibodies in domiciled cats from rio branco Municipality, Acre State, Brazil. Semina: Ciências Agrárias, 36(6), 37573762. doi: 10.5433/1679-0359.2015v36 n6p3757

Teixeira, W. F. P., Lopes, W. D. Z., Cruz, B. C., Maciel, W. G., Felipelli, G., Soares, V. E.,... Costa, A. .J. (2019). Excreção de oocistos de Toxoplasma gondii em felinos primoinfectados com o isolado III. Pubvet, 13(2), 1-7. doi: 10.31533/pubvet. v13n2a273.1-7

Zulpo, D. L., Sammi, A. S., Santos, J. R. dos, Sasse, J. P., Martins, T. A., Minutti, A. F.,... Garcia, J. L. (2018). Toxoplasma gondii: a study of oocyst re-shedding in domestic cats. Veterinary Parasitology, 249(1), 1720. doi: 10.1016/j.vetpar.2017.10.021 
